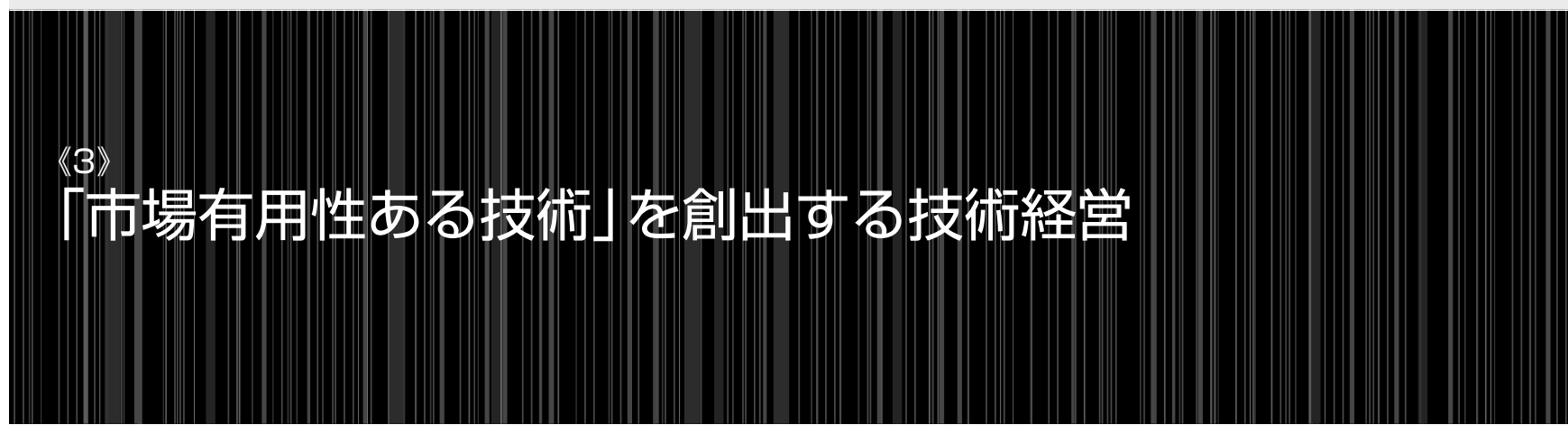

西口泰夫†

1 ま え がき

日本の電気機器産業の収益性は1970年代半ばから大きく低 下し，その後，長期に渡り低迷していることは日本社会お よび日本経済に大きなマイナスのインパクトを与えている.

日本の電気機器産業の収益性に変化が見られる1970代半ば から，重要な技術革新がグローバルに生じている，それは 18 世紀にイギリスから始まった産業革命の原動力である産業 化技術から，20世紀後半の情報革命に伴ってアメリカ中心に 発展している情報化技術へのパラダイムシフトである。こ のパラダイムシフトは単に技術の世界の変化に留まらず, さまざまな社会構造の変化までを引き起こし, 産業化時代 から情報化時代という大きな時代の変化を生み出した。

本稿は，この日本の電気機器産業の収益性の低下および 低迷と，このパラダイムシフトの間に何らかの関係がある と考え,「革新的技術を企業活動の源泉としている日本の
電気機器産業の収益性低下および低迷の一要因は, 企業の 技術経営が産業化時代から情報化時代へのパラダイムシフ トに対応した変化ができていないことにあるのではない か.」との問題意識を提起し, 議論する.

\section{2 情報化時代と日本電気機器産業の経営}

企業の収益性を表す経営指標の中で最も事業活動の結果 を反映するのは営業利益率と考え, 本稿は, 企業の収益性 の指標として営業利益率を採用する１970年から2006年度 までの自動車産業と電気機器産業の売上TOP10企業 (2006 年度東京証券取引所)の単体営業利益率の推移を図1に示す.

両産業の1970年から2006年までの業績推移の結果から， 特筆すべき点は以下の内容である.

1970年～1972年までの営業利益率は，電気機器産業が約 9\%であり，自動車産業は約6.5\%で，横ばいの推移をした後 に両産業とも低下が始まり，上下動を繰り返しながら 1992

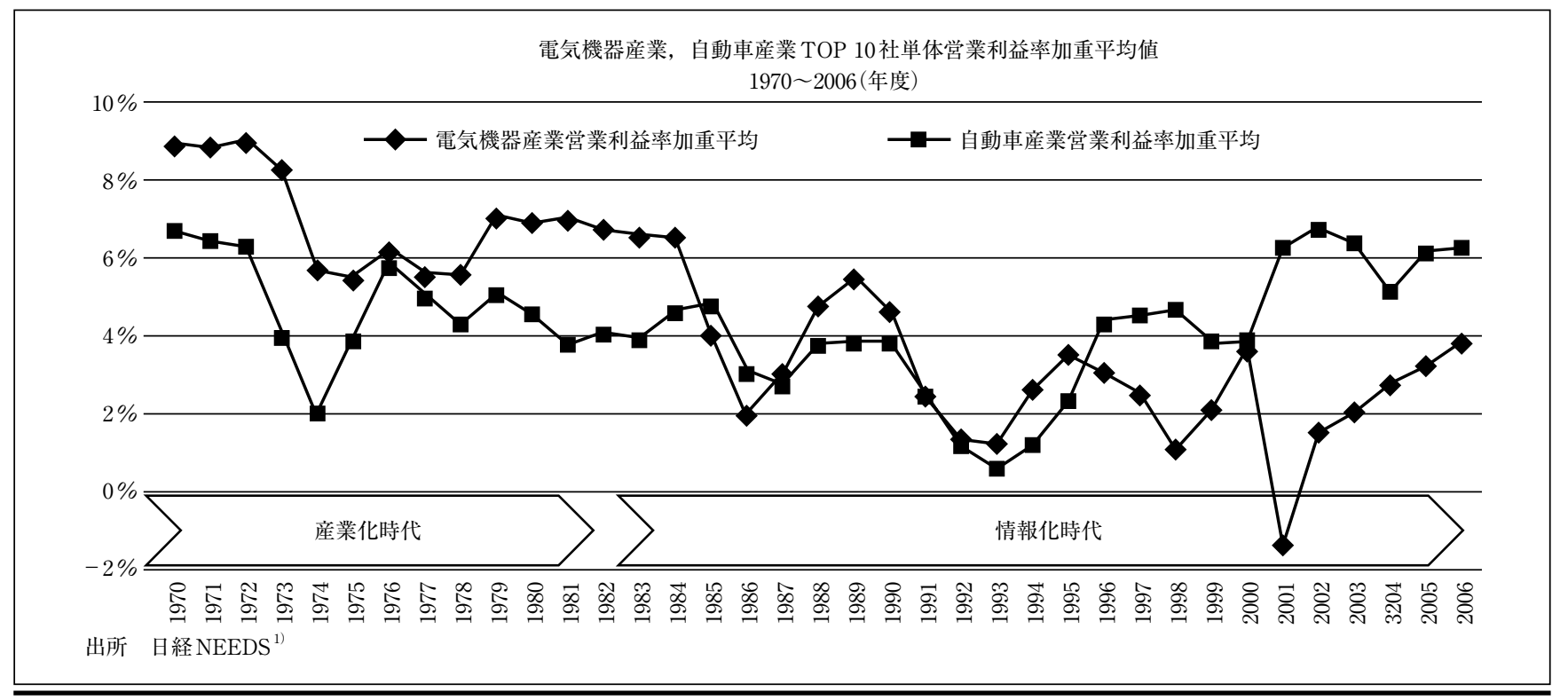

†同志社大学 技術・企業・国際競争力研究センター

図 1 自動車産業TOP 10社と電気機器産業TOP10社の単体営業利益

"Management Based on Technology to Create "Marketable Technology" " 率の推移

by Yasuo Nishiguchi (Institute for Technology, Enterprise and

Competitiveness, Doshisha University, Kyoto) 
年〜1993年において, 約 $1 \%$ と最低となった. その後, 自動 車産業は上下動を繰り返しながら大きくみて右肩上がりの 推移を示し，1970年のレベルまでに回復している。一方， 電気機器産業は1995年に $3.5 \%$ 前後まで回復したものの, そ れ以降において自動車産業を絶えず下回っている．特に 2001年度に赤字を計上して以来，その差は大きなものとな っている. 両産業とも1970年から1993年頃までは, 収益性 において同様の推移をしていることから, 同様なマクロ的 経済環境変化の影響を受け続けた結果と考えられる. しか し1993年以降の電気機器産業の営業利益率低迷は, 同時期 に回復が見られている自動車産業と対比して, 電気機器産 業固有の何らかの経営課題に起因していると考えられる.

一方，1980年前後に米国を中心として産業化時代から情 報化時代へとグローバル市場においてパラダイムシフトが 生じている. 図1に見られるように, 日本の電気機器産業 の収益低迷とこのパラダイムシフトがほぼ同一時期に存在 することから, 電気機器産業固有の経営課題は「企業の技 術経営が産業化時代から情報化時代へのパラダイムシフト に対応した変化ができていない」であると考える。

2.1 情報化が引き起こす構造変化と収益構造変化

電気機器産業の収益性に関しては，これまでに多くの研 究が多方面からなされている.

小川 ${ }^{2)}$ は, 光ディスク産業を例にしてこの営業利益率 低迷の構造を解き明かしている. 図2に示すように，1995 年以降の日本のエレクトロニクス産業のTOP10社の営業利 益率は, エレクトロニクス以外のTOP64社の平均に比べて 大きく乘離した状況となり現在に至っている.

この収益率の長期的な低迷という現象は, 機器がアナロ グからディジタルへ移行するに伴って, 製品アーキテクチ ヤ・産業構造・付加価值構造が大きく変化する中におい

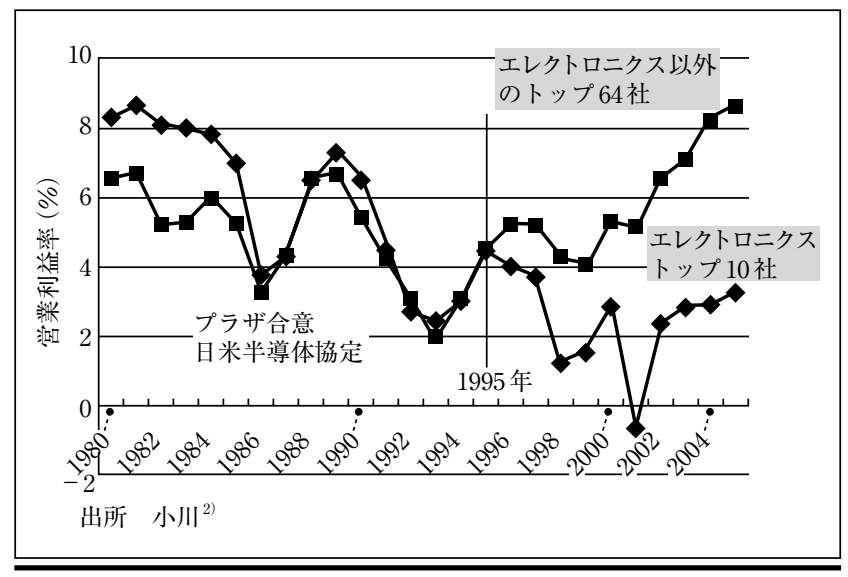

図2 我が国エレクトロニクス産業に見る「失われた10年」
て, 日本の電気機器産業が構造的に追随できなかったこと が最大の要因であると述べている.

小川223)の指摘する構図を図3に示す. 電気機器がアナロ グからディジタルに移行するにしたがって, その制御部分 であるマイコンの高度化が進行し，そこに書かれる制御内 容がファームウェアとして大型化していった．また，必然 の結果として，インタフェースに関する国際的な標準化が 進み, 同時にモジュラ化が進行していった。 これらの動き は，アナログからディジタルへの移行に伴って生じる基本 的で，かつ自然な潮流であった。

これを異なる視点, つまり製品のアーキテクチャ構造と いう面から見ると, 日本の電気機器産業が得意とする擦り 合せ型からモジュラ型への変化と見ることができる．また， 産業構造という面から見ると, これも日本の電気機器産業 が得意とする企業内垂直統合から, 企業間の国際的水平分 業が進んだモジュールクラスタ型構造への変化と見ること ができる，これに伴い利益を生む付加価值は，完成品から 基幹部品, 特にアクティブ型の基幹部品へと移っていった. このような基本的，かつ自然な潮流の中で，擦り合わせ技 術のブラックボックス化を図りつつインタフェースを公開 して, モジュールクラスタ型の産業構造を積極的に活用し たアクティブ型基幹部品を持つ企業に利益が集中するよう になった。このようなプラットフォーム戦略を構築できた 企業のみが利益を享受していると言われる.

擦り合わせ型技術を得意とし, 加えて企業内垂直統合を 標榜した日本の電気機器産業は, このような産業構造の変 化への対応が鈍く, さらに, プラットフォーム戦略を構築 することにあまり関心を払わなかったことに加えて，ほと んどを自前主義で進める技術経営とリニアモデル技術経営 が基本であった。例としてあげると, 産業化時代の電気機

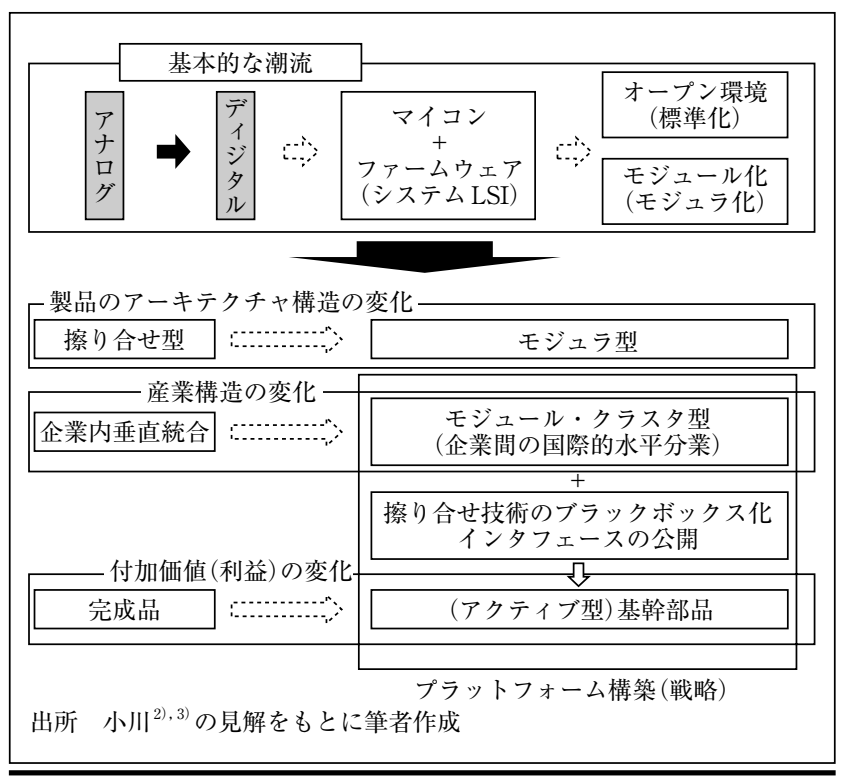

図3情報化技術が引き起こすさまざまな構造変化 
器製品を代表するアナログテレビがある，真の基本技術は 米国からの導入を図ったが，周辺的基礎技術は企業内の研 究所が担当し, 技術部門が応用技術の開発を行った. その 技術を用いて事業部門が商品開発を行い, 商品を市場投入 する. また, 機器に使用する部品類の多くは自社の部品部 門が開発から製造までを行ったものを活用するという構造 である。

その結果，企業内の技術側で起きるイノベーションが， そのまま国際競争力に直結した経営構造, すなわち, アナ ログ時代のリニアモデル技術経営が成立した幸福な経営構 造から抜け切れず, アーキテクチャ・産業構造 ·付加価值 の存在が大きく変化した時代に対応できなかった．営業利 益が低迷する経営環境へ变化したにもかかわらず, 技術経 営が追随できずに営業利益が長期にわたって大きく低迷す る時代に突入していったと考える.

\section{2 情報化時代と世界のICT企業の成長}

このことを別の視点から議論を行う。図4は情報通信白 書 $(2008)^{4)}$ からの引用である.ここでは, 売上高1兆円以 上の世界のICT (情報通信関連) 企業の設立年が記されてお り, そのほとんどは本稿で対象としている電気機器産業で ある.この資料を見ると, 産業化時代から情報化時代への パラダイムシフトへの各地域, 各企業の対応の結果を読取
れる。

米国では1900年前後に東海岸を中心に電気機器産業が勃 興し，隆盛を極める企業に成長した。さらに，ICT産業が 勃興し始めた1960年以降では西海岸を中心として，再び多 くの企業が産声を上げ大企業へと育っている．本稿はこの 辺りから情報化時代が始まったと捉えている．欧州におい ても同様の状況である。またアジアにおいては，1960年以 降に多くのICTベンダーとしての新興企業が生まれ育って いる.これに対して日本では, 多くの企業が1920年頃から 1960年までの約40年間に誕生している。第2次世界大戦を 挟むこの頃は，まさに日本の電器機器産業の黎明期とも言 える時期である。これらの企業群は, その後の高度成長期 を経て, 売上高1兆円以上という大企業に成長した。具体 的には，1900年前後に生まれたNEC・東芝，1920年以降に 生まれた日立製作所, 松下電器産業, 富士通, シャープ, キヤノン, ソニー, 三洋電機などが本稿の対象となる電気 機器産業である. これらの企業の特徵は, 個々の企業の業 態は異なるといえども, さまざまな事業ドメインを持つ総 合電機メーカであるという点である.

一方，このデータでは世界の他の地域と異なり，日本にお いては, ICT産業勃興期の1960年以降には一社も新たな企業 が生まれていないことになる.NTTデータは, NTTからの

\begin{tabular}{|c|c|c|c|c|c|c|c|c|}
\hline \multirow[b]{2}{*}{$1990 \sim$} & \multicolumn{2}{|l|}{ 日本 } & \multicolumn{2}{|l|}{ 北米 } & \multicolumn{2}{|l|}{ 欧州 } & \multicolumn{2}{|l|}{ アジア } \\
\hline & & & Google & 1998 & (Infineon) & 1999 & $\begin{array}{c}\text { (AU Optronics) } \\
\text { Asustek }\end{array}$ & $\begin{array}{l}2001 \\
1990\end{array}$ \\
\hline $1980 \sim$ & (NTTデータ) & 1988 & $\begin{array}{c}\text { Qualcomm } \\
\text { Dell } \\
\text { Cisco } \\
\text { Sun Microsystems }\end{array}$ & $\begin{array}{l}1985 \\
1984 \\
1984 \\
1982\end{array}$ & & & $\begin{array}{l}\text { Quanta } \\
\text { Lenovo } \\
\text { Compal }\end{array}$ & $\begin{array}{l}1988 \\
1984 \\
1984\end{array}$ \\
\hline $1970 \sim$ & & & $\begin{array}{c}\text { Seagate } \\
\text { EMC } \\
\text { Oracle } \\
\text { Apple } \\
\text { Microsoft }\end{array}$ & $\begin{array}{l}1979 \\
1979 \\
1977 \\
1976 \\
1975\end{array}$ & SAP & 1972 & $\begin{array}{c}\text { Acer } \\
\text { Hon Hai }\end{array}$ & $\begin{array}{l}1976 \\
1974\end{array}$ \\
\hline $1960 \sim$ & & & $\begin{array}{l}\text { SAIC } \\
\text { Intel } \\
\text { EDS }\end{array}$ & $\begin{array}{l}1969 \\
1968 \\
1962\end{array}$ & $\begin{array}{c}\text { (Nokia) } \\
\text { CapGemini }\end{array}$ & $\begin{array}{l}1967 \\
1967\end{array}$ & Samsung & 1969 \\
\hline $1950 \sim$ & $\begin{array}{l}\text { 京セラ } \\
\text { 三洋電機 }\end{array}$ & $\begin{array}{l}1959 \\
1950\end{array}$ & $\mathrm{CSC}$ & 1959 & & & LG電子 & 1958 \\
\hline $1930 \sim$ & $\begin{array}{c}\text { ソニー } \\
\text { セイコーエプソン } \\
\text { キャノン } \\
\text { リコー } \\
\text { コニカミノルタ } \\
\text { シャープ } \\
\text { 富士通 } \\
\text { 松下電器産業 } \\
\text { 富士フィルム }\end{array}$ & \begin{tabular}{l|}
1946 \\
1942 \\
1937 \\
1936 \\
1936 \\
1935 \\
1935 \\
1935 \\
1934
\end{tabular} & $\begin{array}{l}\text { Tyco Electronics } \\
\text { HP } \\
\text { Texas Instruments }\end{array}$ & $\begin{array}{l}1941 \\
1939 \\
1930\end{array}$ & & & & \\
\hline $1900 \sim$ & $\begin{array}{c}\text { 三菱電機 } \\
\text { 日立製作所 } \\
\text { オリンパス } \\
\text { 東芝 }\end{array}$ & $\begin{array}{l}1921 \\
1920 \\
1919 \\
1904 \\
\end{array}$ & $\begin{array}{l}\text { Motorola } \\
\text { IBM } \\
\text { Xerox }\end{array}$ & $\begin{array}{l}1928 \\
1914 \\
1906\end{array}$ & & & & \\
\hline$\sim 1900$ & NEC & 1899 & $\begin{array}{c}\text { Nortel } \\
\text { Eastman Kodak }\end{array}$ & $\begin{array}{l}1895 \\
1880\end{array}$ & $\begin{array}{c}\text { Alcatel-Lucent } \\
\text { Philips } \\
\text { Ericsson } \\
\text { Siemens }\end{array}$ & $\begin{array}{l}1898 \\
1891 \\
1876 \\
1847\end{array}$ & & \\
\hline
\end{tabular}




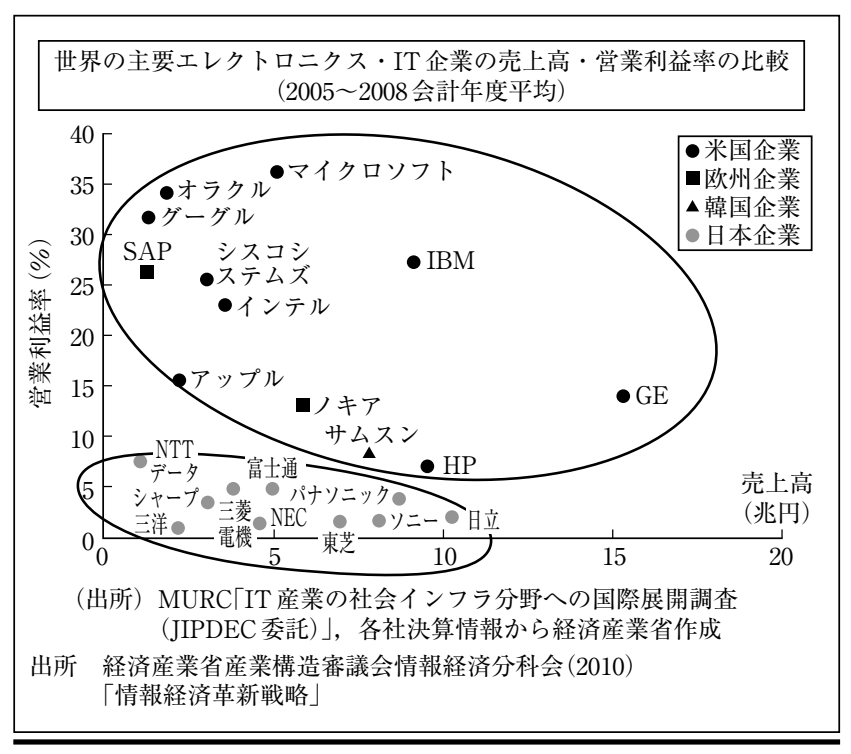

図5 世界と日本の主要プレ一ヤの売上高·営業利益率比較
我が国が誇る代表的なプロダクト・イノベーション，しかし…… 液晶に関する工業所有権の現状

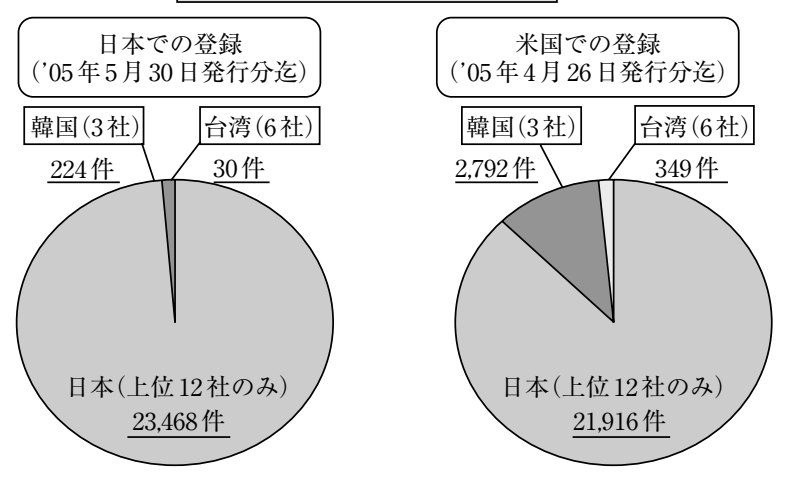

DVD も日本企業が必須特許の $90 \%$ 以上を持つ, しかし..

出所 小川紘一(東京大学)

図6 我が国が液晶パネルの技術開発・市場開拓を主導
分社により生まれたため新規創業とは位置づけできない，

さらに図5に，その後の世界のエレクトロニクス・ICT企 業の売上高・営業利益率に関する経営状況を表す.このデ 一タから明らかなように, 日本の電気機器産業は他の国の 企業に比較して, 特に企業のパフォーマンスを表す営業利 益率に扔いては大きく下回っている。これらの事実から同 じ産業において, 特に情報化時代においては, 世界の企業 に比べ明らかに日本企業の収益性が低く, 成長性が低いと 言える.

\section{3 情報化時代と日本電気機器産業の技術経営}

もう少し焦点を絞り，日本企業のどのような点に問題が あったのかを議論する，小川213)によると，図6に示すよう に，2005年における液晶に関する米国での特許登録件数は， 日本企業が約 2 万 2,000 件で圧倒的に多い. 韓国, 台湾企業 は合わせて 3,000 件強で全体の $15 \%$ 足らずである．またDVD についても必須特許の数では日本が圧倒している.このデ ータが示すように, 日本企業は特許を得ることができた先 進性のある技術を数多く持つにもかかわらず, 経営では圧 倒的に負けている. まさに, 技術で勝って事業で負けてい るという結果である.

\section{1 特許の活用度合いとパフォーマンスの関係}

なぜ日本企業では特許力が事業力に反映されていないか を見るために，企業における特許の活用度合いを明らかに し，さらにそれとパフォーマンスの関係を議論する5).

特許の活用度合いを見るために，特に登録総数に対する 登録後 6 年間の間に権利放棄されて消滅する特許累積数の 比率に着目した。本来ならば企業は，この期間に研究開発 費の支出により得た特許化された貴重な技術を新商品に活
用することにより，競合他社との差別化を図ることを行い， 結果として，営業利益率に大きく貢献することを期待する との考えからである。一方，この期間に権利放棄される特 許は，その特許の持つ技術の事業的価值が，その特許の登 録維持費との経済的バランスからみて不利と判断されたも のである.すなわち，特許の活用度合いは，特許の持つ事 業価値をも意味していると考えられる.

ある年に登録された特許が，本来ならば活用が見込まれ る6年以内に権利放棄される割合を，IIPパテントデータベ ース (Institute of Intellectual Property)のデータを基に算 出した結果を表1に示す.

この割合を登録特許消滅率とする，結果から企業間差は 見られるが，特に大手総合電気企業の登録特許消滅率が高 い.すなわち，これらの企業において，多くの特許は活用 されないことが明らかである.

さらに，このような特許の活用度合いが，企業のパフォ ーマンスにどのように関与するかを見るために, これらの 相関を見る. 本稿におけるモデルは, 被説明変数である営 業利益率と説明変数として用いる研究開発費比率, 特許登 録件数および登録特許消滅率との時間的な関係を含め, 図 7の概念図に基づいて設定する.

複数年間における研究開発投資の結果として得られた技 術成果が，特許出願を経て特許登録される.ささらにその特 許化された技術を活用した商品が，企業の売上と利益の複 数年計上に貢献するには，それぞれの間にはタイムラグが あると考えられる。

村上 $^{6}$ おうよび榊原 $^{7}$ は研究開発の効率の算出において, 5 年 間の研究開発投資の効果は, 研究開発投資後 5 年間の利益と して出る，というラグ構造を提唱している.ささらに，利益 指標は一般的に短期的な影響を受けやすいので，この点を 
表1 日本の電気機器産業のTOP 10 社の登録特許消滅率

(登録数に対する6年間に消滅した数の割合)

\begin{tabular}{|c|c|r|r|r|r|r|r|r|r|r|r|r|}
\hline & 1985 & 1986 & 1987 & 1988 & 1989 & 1990 & 1991 & 1992 & 1993 & 1994 & 1995 & 1996 \\
\hline \hline 日立 & 22.5 & 30.4 & 35.9 & 32.8 & 29.6 & 31.3 & 32.4 & 40.0 & 48.3 & 45.1 & 47.9 & 37.4 \\
\hline 東芝 & 15.6 & 20.0 & 24.2 & 22.4 & 15.5 & 18.6 & 27.0 & 29.4 & 28.9 & 30.9 & 32.6 & 24.4 \\
\hline 三菱電機 & 20.3 & 18.0 & 26.2 & 29.4 & 28.1 & 30.7 & 37.4 & 37.8 & 40.3 & 41.1 & 37.3 & 31.8 \\
\hline 日本電気 & 12.2 & 4.7 & 0.9 & 12.2 & 9.6 & 10.7 & 11.1 & 10.1 & 15.5 & 34.7 & 46.9 & 34.6 \\
\hline 富士通 & 24.0 & 18.5 & 34.7 & 31.9 & 21.8 & 32.4 & 34.8 & 41.5 & 40.0 & 41.1 & 45.0 & 37.0 \\
\hline 松下電 & 14.3 & 16.9 & 15.7 & 25.8 & 32.3 & 36.1 & 39.2 & 37.4 & 34.0 & 33.0 & 30.0 & 22.9 \\
\hline シャープ & 13.3 & 9.0 & 9.6 & 7.5 & 6.2 & 7.9 & 2.3 & 5.9 & 6.8 & 10.5 & 8.9 & 8.8 \\
\hline ソニー & 14.5 & 16.8 & 20.7 & 16.2 & 8.9 & 9.3 & 3.1 & 7.0 & 8.8 & 2.9 & 1.8 & 2.6 \\
\hline 三洋電機 & 8.1 & 41.8 & 35.1 & 36.6 & 43.4 & 39.1 & 32.2 & 38.5 & 41.0 & 36.0 & 35.7 & 26.3 \\
\hline キャノン & 2.0 & 2.1 & 1.1 & 1.6 & 3.5 & 1.3 & 4.6 & 6.1 & 2.4 & 2.3 & 1.9 & 2.1 \\
\hline
\end{tabular}

出所:IIPパテントデータベースのデータを基に筆者作成

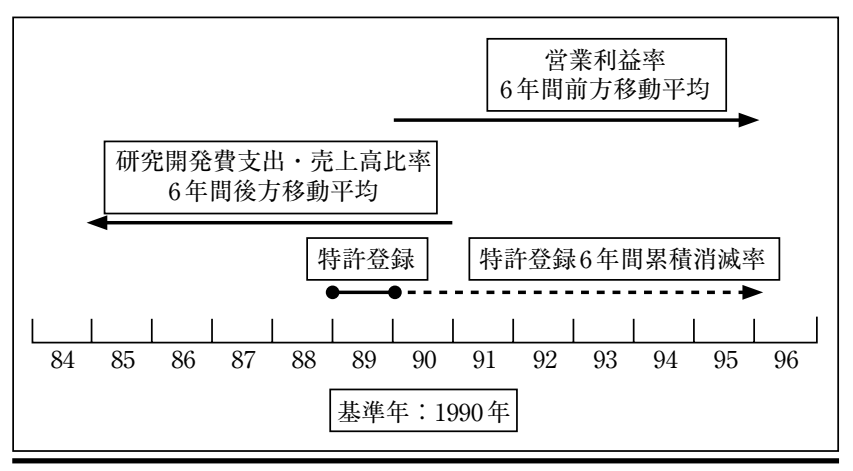

図7 モデルの概念図

考慮して5年間の移動平均で計算すべきだと主張している.

本稿におけるモデルはラグを 5 年と設定し, 図7に研究開 発費支出, 特許登録と消滅および営業利益率のタイムラグ と移動平均の概念を示す. 6 年の移動平均を採用した理由 は, 後述するように, 特許の消滅率算出期間として6年を 採用したことに整合させたことによる。

図7を用いて，時間の側面からモデルの説明を行う．例 として1990年を説明のための基本年とする. 研究開発費比 率 (研究開発費支出・売上高比率) は先述の理由により6年 間，1985～1990年の後方移動平均值をとる.これに対応す る営業利益率は同様に6年間，1990～1995年の前方移動平 均值とする。これらに対応する特許登録は，市場投入によ る利益計上の1年前まで完了させるという考えに基づき， 1 期のラグを採用して1989年のものとする.

先の登録特許消滅の考えに基づき, 経営的価值が低い特 許は特許権利が放棄されて消滅すると考え，1989年の登録 特許の内，その後6年間に何\%が消滅したかをもって登録特 許消滅率として算出する.すなわち，1989年の登録特許消 滅率は，1989年の登録の後6年間に更新をされずに権利放 棄された特許の累積数を1989年の登録特許総数で除した值 である. 以上のように，それぞれの変数固有の実情による タイムラグを考慮することで, モデルの経済合理性を確保 する。

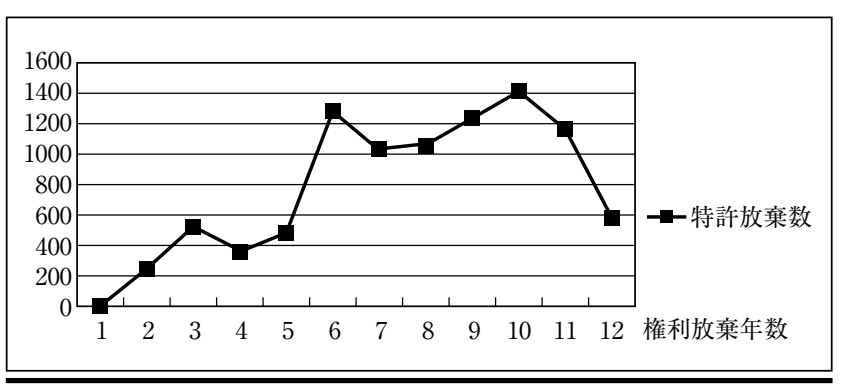

図8 サンプル企業 10 社の1990年登録特許の権利放棄合計数の推移図
登録特許消滅率算出の期間設定を6年と設定した理由を あらためて以下に述べる. 図8は, サンプル企業10社の 1990年登録特許の権利放棄合計数の推移である。3年目，6 年目と 10 年目に権利放棄件数のピークが見られる. 3 年目 と6年目は, 特許料が大幅に増加する 4 年目と 7 年目のそれ ぞれの前年である。このデータから，企業は特に登録維持 費用が高くなる年の前に, その特許の持つ経営的価值を考 慮して維持または放棄の判断をしていると考えられる. 7 年目から11年目までには多くの特許の権利放棄が見られ る.これは技術の陳腐化が進んだことと毎年の高い維持費 用が最大の要因だと考えられる，そして 12 年目には消滅数 が激減している．これは，権利を維持する特許の総数が減 少したことと，さらに長期にわたって権利を維持すべき特 許が明確になったためと推測できる。

このように，特許化された技術の経済価值と登録維持コ ストの経営的バランスが権利放棄という判断に大きな影響 を与えていると解釈できる.

\section{2 回帰分析結果}

推計結果を表2に示す．結果を見やすくするために, 被 説明変数である営業利益率は百分率 $(\%)$, 説明変数で比率 を用いた変数は実数值(小数值)によって回帰を行っている.

回帰分析結果から，登録特許消滅率の係数はマイナスで 有意となっている，登録特許消滅率 $1 \%$ の上昇が営業利益率 
表2 回帰分析結果

\begin{tabular}{|c||r|r|r|r|}
\hline \multicolumn{1}{|c||}{ 被説明変数 } & \multicolumn{4}{|c|}{ 営業利益率 $(6$ 年前方移動平均 $)$} \\
\hline 説明変数 & 係数 & $t$ 值 & $p$ 值 & \\
\hline 定数項 & -40.771 & -5.094 & 0.000 & $* *$ \\
\hline 登録特許消滅率・1期ラグ & -3.768 & -4.092 & 0.000 & $* *$ \\
\hline 対数特許登録数・1期ラグ & 0.756 & 1.574 & 0.120 & \\
\hline 研究開発費比率 & -10.058 & -1.307 & 0.196 & \\
\hline レバレッジ & -6.498 & -1.638 & 0.106 & \\
\hline 対数従業員数 & 3.809 & 4.740 & 0.000 & $* *$ \\
\hline $\mathrm{R}^{2}$ & 0.887 & & & \\
\hline Adi. R ${ }^{2}$ & 0.851 & & & \\
\hline DW & 0.426 & & & \\
\hline F 值 & 24.318 & & 0.000 & $* *$ \\
\hline 推計サンプル数 & 95 & & & \\
\hline 推計期間数 & 11 & & & \\
\hline 推計企業数 & 9 & & & \\
\hline
\end{tabular}

に対し，負の方向に㧍よそ $0.038 \% の$ 影響を与えることとな る. 例えば, 表 $1 て ゙$ 約 $30 \%$ の消滅率の存在を見られるが, こ の場合は消滅率の効果によって, その企業の営業利益率を, 1.14\%減少させる影響を与えることになる. 図5から見られ るように, 日本の各企業の営業利益率は数\%レべルである ため, この数値の与える影響は非常に大きい。この結果は, 消滅率が高くなれば営業利益率は下がることを支持してい る.また，質的側面である登録特許消滅率の隇少に基本を おく技術経営が, 企業の収益性向上に寄与することを意味 している. また, 研究開発費比率, 登録特許件数の係数は すべて有意となっていない。この結果は, 研究開発費支出 およびその技術成果が特許登録されただけで, 商品に活用 されなければ必ずしも営業利益率を高めるわけではないこ とと矛盾しないため, 妥当な結果と判断できる.

またこの結果は, 単に量的側面である研究開発費比率お よび登録特許件数を増大することに基本を置く技術経営 が，必ずしも収益性の向上に寄与しないことを意味する。

以上の分析結果から, 研究開発費投資の成果である技術 群が事業に活用されている場合には, それに関連する特許 は登録特許の中でも継続的に更新され続け, 事業の付加価 値を高めて, 営業利益率向上に貢献できることが実証的に 示されたことになる. 反対に活用されなかった場合は, そ れに関連する特許は, それらが生み出す事業への貢献度が 低く, 登録特許維持費用との経営的バランス評価から更新 時期に権利放棄される可能性が高い.この場合には, 研究 開発投資の回収が充分されないことがあり, さらに，投資 された研究開発費はすでに経費計上されているため, 結果 として営業利益率にマイナスの影響を与えることになる。

結論として, 企業の営業利益率を向上させるには, 登録 特許の消滅率を小さくすること, すなわち登録特許の事業 への活用度合いを高めることである。このためには, 事業 価値が高い登録特許を多く持つことを意味し，すなわち，
事業価値の高い技術を多く生み出すことに他ならない. 本 稿は，この種の技術を「市場有用性ある技術」と称している. このような「市場有用性ある技術」を創出する技術経営が， 企業に最も求められていると言える.

\section{4 むす び}

情報化時代に「市場有用性ある技術」を創出する技術経営 には，5つの要素が必要と考える。

(1) 経営戦略と技術戦略の一体化

(2) オープンイノベーション

（3）市場ニーズの的確な把握

(4) 知識経営 (人・組織の持つ知識の共有化と活用)

(5) 人・組織の有機的活用

この5つの構成要素について，その詳細を以下に述べる.

(1) 経営戦略と技術戦略の一体化

情報化時代に求められるビジネス競争条件の多様性・変 化等に企業が対応するためには，経営戦略と技術戦略の一 体化が重要である．企業が持続的成長を目指すためには明 確な経営戦略があり，その実現をはかるための技術戦略を， 経営部門と技術部門が一体となって企画し，その実行にあ たることが重要である.

(2) オープンイノベーション

情報化時代において，市場ニーズを捉えた商品をタイムリ 一に市場投入するためには, 研究・開発の成果である技術 をタイムリーに獲得することが必須である。これには，必 要とする技術を自社内のみに限らず，外部からも得ること ができるイノベーションプロセスのオープン化が重要な要 因である. 企業の技術経営は, 研究開発のみならず生産・ 販売・サービスまでのすべてのビジネス・プロセスにおい てオープンノベーションを実現することが基本である.

（3）市場ニーズの的確な把握

企業は情報化時代においては，産業化時代に比べ大規模， かつ多様化するグローバル市場のニーズを，的確に先読み することを行わなければならない.さらに，企業は把握し た市場ニーズの実現に不可欠な革新的技術を獲得するため に，必要な技術開発を先行させる．その後，タイムリーに このニーズを反映した商品を市場投入することが，持続的 経営を行う上で最も重要である. 企業活動としての技術経 営の役割は, 企業外に存在し変化する市場ニーズを的確に 把握し，商品に反映させることにある。

(4) 知識経営 (人・組織の持つ知識の共有化と活用)

産業化時代に扔いては, 付加価值の源泉は工場設備㧤よ びその稼動を行っている製造部門が中心にあったが，情報 化時代には, 付加価值は製品を媒介にした問題解決 (ソリ ユーション)・サービス・情報提供, あるいは, それを組 込んだ新たな生産プロセスに重心が移行している.つまり， 人や組織がつくりだす知識, そしてそれらの知識資産が価 值の源泉となっている．この情報化時代に扔いて企業が収 
益向上を図るには，企業内外を問わず人・組織が持つ潜在 的知識をも顕在化し，その共有・活用による組織綜合力の 具現化を可能とする技術経営を必要である.

(5) 人・組織の有機的活用

企業は機能制組織および事業部制に見られる分業体制に よる効率追求を行っている. 一方, 集団の綜合力の創出面 からは，主に人・組織が持つセクショナリズムおよびその 間のコミュニケーションロスによるデメリットがあること も明らかである．情報化時代においては，人・組織の持つ あらゆる能力の効率的な綜合化が必要である. それを実現 するためには, 企業の技術経営は人・組織の有機的活用を 基本とすべきと考える.

以上5つの要素を持つ技術経営により創出された「市場有 用性ある技術」が事業に貢献することにより，日本の電気機 器産業の新たな経営結果が見出されることを期待したい.

この5つの要素を持つ新たな技術経営の概念を，「技術を 活かす経営」(Management Based on Technology) と呼ん でいる ${ }^{8)}$. 今後の研究として，これらの要素についての更 なる探求と, これらの要素をもった具体的な技術経営の仕 組みの探求を行いたい.

(2011年4月18日受付)

\section{〔文 献〕}

1）日経NEEDS：“日経財務データDVD版”，日経新聞社ディジタルメ ディア局

2）小川紘一：“我が国エレクトロニクス産業にみるモジュラ化の進化メ カニズム—マイコンとファームウェアがもたらす経営環境の歴史的転 換一”，赤門マネジメント・レビュー, 7, 4, p.83（Feb. 2008）

3）小川紘一：“我が国エレクトロニクス産業にみるプラットフォームの 形成メカニズム”, 赤門マネジメント・レビュー, 7, 6, p.339 (June 2008)

4）総務省編：“情報通信白書平成20年度版”（July 2008）

5）西口泰夫：“「市場有用性ある技術」と営業利益率の関係：日本の大 手電気機器産業を事例とした実証研究”, 組織科学, 44, 2, pp7787 (Dec. 2011)

6）村上路一：“機意識から生まれたイノベーション・マネジメント” Works, 37, pp10-13 (Dec. 1999)

7）榊原清則：“イノベーションの収益化一技術経営の課題と分析”, 有 斐閣（2007）

8）西口泰夫：“技術を活かす経営”，白桃社（2009）

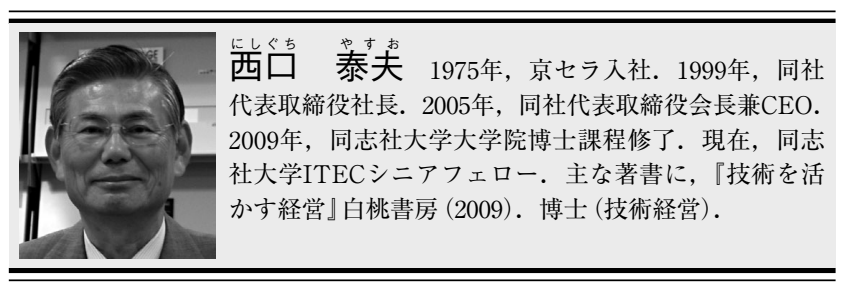

